\title{
Autoradiographic Determination of Regional Cerebral Blood Flow during Hypoglycemia in Newborn Dogs
}

\author{
MUJAHID ANWAR AND ROBERT C. VANNUCCI \\ Department of Pediatrics (Newborn Medicine), Robert Wood Johnson Medical School and St. Peter's Medical \\ Center, New Brunswick, New Jersey 08903 and Department of Pediatrics (Pediatric Neurology), The Milton S. \\ Hershey Medical Center of The Pennsylvania State University, Hershey, Pennsylvania
}

\begin{abstract}
To ascertain the regional cerebral blood flow (CBF) responses to hypoglycemia, nine newborn dogs were treated with insulin to blood glucose concentrations ranging from 1 to $35 \mathrm{mg} / \mathrm{dl}$ (mean $22 \mathrm{mg} / \mathrm{dl}$ ). Systemic physiologic monitoring revealed no differences in mean arterial blood pressure, heart rate, $\mathrm{paO}_{2}, \mathrm{paCO}_{2}, \mathrm{pHa}$, or blood lactate in the hypoglycemis animals and five normoglycemic controls. Significant increases in CBF occurred in 17 of 20 analyzed structures of brain in the hypoglycemic puppies, ranging from 158 to $446 \%$ of the normoglycemic values. The percent increases in CBF were greatest in brainstem structures compared to other major regions of brain. A positive correlation existed between mean arterial blood pressure and cerebral cortical blood flow, suggesting a loss of CBF autoregulation during hypoglycemia. The pathophysiologic mechanism for the elevations in regional CBF might relate to stimulation of $\beta$-adrenergic receptors in brain, as has been shown in adults. (Pediatr Res 24: 4145, 1988)
\end{abstract}

Abbreviations

CBF, cerebral blood flow

rCBF, regional CBF

MABP, mean arterial blood pressure

PCA, perchloric acid

Hypoglycemia, defined as a blood glucose concentration of $<30 \mathrm{mg} / \mathrm{dl}$ in full-term infants and $<20 \mathrm{mg} / \mathrm{dl}$ in premature infants, is a common clinical problem in high risk newborn infants (1-5). Asymptomatic hypoglycemia has not been associated with adverse neurologic sequelae, whereas up to $60 \%$ of infants exhibiting symptomatic hypoglycemia suffer permanent brain damage (6-8). Premature and small for gestational age infants are especially vulnerable to hypoglycemic brain injury $(2$, $9,10)$. However, offspring of diabetic mothers appear to be at less risk for symptomatic hypoglycemia and ultimate brain injury $(4,6-8)$.

The underlying pathophysiologic mechanism(s) producing brain dysfunction and clinical symptoms in hypoglycemic newborn infants is not entirely known. Hypoglycemic brain damage presumably results from inadequate mobilization and utilization

Received November 12, 1987; accepted February 29, 1988.

Correspondence Mujahid Anwar, M.D., Department of Pediatrics, St. Peter's Medical Center, 254 Easton Avenue, New Brunswick, NJ 08903-0591.

Supported in part by Grant 15738 from The National Institute of Child Health and Human Development and by a Grant from The American Diabetes Association, New York affiliate. of alternate cerebral metabolic fuels; specifically ketone bodies, lactic acid, and amino acids; or from an accumulation of one or more toxic metabolites in brain when these alternate fuels are consumed. Investigations have shown that whereas glucose consumption is reduced during hypoglycemia, oxygen consumption is essentially unchanged (11-14); indicating that alternate fuels are being used for energy production. In this regard, Geiger (15) has shown that the perfused adult cat brain is capable of functioning for more than $1 \mathrm{~h}$ without exogenous glucose so long as a high perfusion rate is maintained. This finding suggests that while the brain is able to use endogenous noncarbohydrate substrates for energy production, hypoglycemic symptoms and ultimate brain injury are, at least in part, due to the local accumulation of toxic breakdown products of these substrates. Thus, changes in CBF adversely affecting any region of the brain would allow the local accumulation of toxic metabolites, resulting in brain injury.

We previously have determined the blood flow responses of newborn dog cerebral cortex to insulin-induced hypoglycemia using an arteriovenous technique with ${ }^{133}$ Xenon as the diffusible indicator (14). In that study, no differences in CBF were observed in normoglycemia and hypoglycemic animals. Now that techniques are available to measure $\mathrm{rCBF}$, we decided to study the regional distribution of blood flow in the brain during hypoglycemia in newborn dogs in an attempt to ascertain the vulnerability of specific structures to hypoglycemic brain damage.

\section{MATERIALS AND METHODS}

Newborn Beagle dogs of 2 to 5 days postnatal age initially were anesthetized with halothane (4\% induction; $1 \%$ maintenance), tracheostomized, and paralyzed with pancuronium bromide $1.0 \mathrm{mg} / \mathrm{kg}$ body weight subcutaneously. The puppies then were artificially ventilated with a gas mixture of $70 \%$ nitrous oxide- $30 \%$ oxygen by means of a small animal respirator (Harvard Apparatus Co., Inc., S. Natick, MA). A femoral artery was catheterized under local anesthesia (procaine $\mathrm{HCl} 1 \%$ ) for the continuous recording of systemic blood pressure via a Statham transducer connected to a dynographic recorder (Beckman Instruments Inc., Fullerton, CA). The arterial catheter also allowed for intermittent collection of blood $(\sim 0.2 \mathrm{ml})$ for measurement of $\mathrm{paO}_{2}, \mathrm{paCO}_{2}$, and $\mathrm{pHa}$ on a microelectrode system (Corning Medical, Medford, MA). Additional blood specimens $(0.02 \mathrm{ml})$ were obtained and immediately diluted $1: 10$ in $0.5 \mathrm{M}$ perchloric acid for later determination of glucose and lactate concentrations by standard enzymatic techniques $(16,17)$. The total volume of blood removed was similar in all animals and amounted to no more than $1.5 \mathrm{ml}$, which is less than $5 \%$ of the circulating blood volume of the newborn dog. Rectal temperature was maintained at $37 \pm 0.5^{\circ} \mathrm{C}$ by means of a thermister controlled heating lamp. 
When the newborn dogs had achieved normal arterial oxygen and acid-base balance $\left(\mathrm{paO}_{2} 70-110 \mathrm{~mm} \mathrm{Hg} ; \mathrm{paCO}_{2} 35-45 \mathrm{~mm}\right.$ $\mathrm{Hg}$; $\mathrm{pHa}$ 7.35-7.45), hypoglycemia was induced by the intravenous injection of regular insulin USP $0.2 \mathrm{U} / \mathrm{g}$ body weight; control animals received an equivalent volume of $\mathrm{N} \mathrm{NaCl}$. Hypoglycemia, with final blood glucose concentrations at or below $35 \mathrm{mg} / \mathrm{dl}$, was achieved within 90-120 min.

rCBF was measured by the indicator-fractionation method as originally described by Van Uitert and Levy (18) and applied to the newborn dog by Cavazzuti and Duffy (19). The radioisotope 4-iodo- $\left[{ }^{14} \mathrm{C}\right]$-antipyrine $(59 \mathrm{mCi} / \mathrm{mM}$ : New England Nuclear, Boston, MA) was used as the diffusible indicator, and the quantity of the indicator accumulated in brain was assessed by ${ }^{14} \mathrm{C}$ autoradiography. This technique is based on the Fick equation:

$$
\mathrm{CBF}=\frac{\mathrm{Q}(\mathrm{t})}{\int_{0}^{\mathrm{t}}(\mathrm{Ca}-\mathrm{Cv}) \mathrm{dt} \times 100}
$$

where $\mathrm{CBF}$ is in $\mathrm{ml} / 100 \mathrm{~g} / \mathrm{min} ; \mathrm{Q}(\mathrm{t})$ is the amount of indicator accumulated in brain during time $(\mathrm{t})$; and $(\mathrm{Ca}-\mathrm{CV}) \mathrm{dt}$ is the integrated difference between amount of indicator in arterial and venous blood.

If a freely diffusible indicator is used and the time from bolus injection to animal death is relatively brief (s) so that venous outflow is negligible, then the integrated arterial concentration can be used as an approximation of the integrated arteriovenous difference (18). Furthermore, if the integrated arterial indicator concentration is the same for two organs and the time from bolus injection to termination of organ blood flow is also the same, then the ratio of the indicator to blood flow will be the same for the two organs. Thus,

$$
\frac{\mathrm{Q}_{\mathrm{i}}(\mathrm{t})}{\mathrm{CBF}_{\mathrm{i}}}=\int_{0}^{\mathrm{t}} \mathrm{Ca}_{\mathrm{i}} \mathrm{dt}=\int_{0}^{\mathrm{t}} \mathrm{Ca}_{\mathrm{ii}} \mathrm{dt}=\frac{\mathrm{Q}_{\mathrm{ii}}(\mathrm{t})}{\mathrm{CBF}_{\mathrm{ii}}}
$$

An artificial organ was produced by withdrawing blood into a syringe at a specified constant rate. Thus,

$$
\mathrm{CBF}=\frac{\text { brain counts }(\mathrm{dpm})}{\text { brain mass }(\mathrm{g})} \times \frac{\text { arterial flow }(\mathrm{ml} / \mathrm{min})}{\text { arterial counts }(\mathrm{dpm})}
$$

Cavazzuti and Duffy (19) have shown that the optimal circulation time for ${ }^{14} \mathrm{C}$-iodoantipyrine is $9 \mathrm{~s}$. At $9 \mathrm{~s}$ the intregral of venous radioactivity in newborn dogs is $<5 \%$ of the integral of the arterial radioactivity, thus satisfying the requirement of negligible venous outflow at the time of the animal's death.

For measurement of $\mathrm{rCBF}$ in the newborn dog, the femoral artery catheter was connected via polyethylene tubing $(5-7 \mathrm{~cm}$ in length) to a syringe set in a Harvard infusion/withdrawal pump calibrated to withdraw blood at a constant rate of 1.57 $\mathrm{ml} / \mathrm{min}$. At 0 time, $50 \mu \mathrm{Ci}$ of ${ }^{14} \mathrm{C}$-iodoantipyrine dissolved in 0.5 $\mathrm{ml}$ of $0.9 \% \mathrm{NaCl}$ were injected rapidly through the venous catheter and the withdrawal pumps started. At $9 \mathrm{~s}$ the animal was decapitated with a small animal guillotine and the arterial catheter rapidly disconnected. The brain was quickly removed from its skull and frozen in freon 12 chilled to $-65^{\circ} \mathrm{C}$. The blood collected in the syringe was expelled into a tube containing 1.0 $\mathrm{ml}$ of water. An aliquot of the mixture then was solubilized in $0.5 \mathrm{ml}$ of Protosol (New England Nuclear) and later diluted in $10 \mathrm{ml}$ of Omnifluor-Toluene scintillation cockatail (New England Nuclear). The mixture then was counted in a scintillation spectrometer (Beckman) with appropriate standards and blanks.

Coronal sections of the frozen brain were cut at $20-\mu$ thickness in a cryostat (American Optical, Buffalo, NY) at $-15^{\circ} \mathrm{C}$. The sections were mounted on glass coverslips, dried at $55^{\circ} \mathrm{C}$, and subjected to quantitative ${ }^{14} \mathrm{C}$-autoradiography along with calibrated ${ }^{14} \mathrm{C}$-methylmethacrylate standards. Comparison of the optical densities of 1-2 mm diameter portions of the autoradiograms corresponding to specific brain regions with the optical densities of the ${ }^{14} \mathrm{C}$ standards yielded the concentration $(\mathrm{nCi} / \mathrm{g})$
Table 1. Systemic physiologic variables during normoglycemia and hypoglycemia in newborn dogs*

\begin{tabular}{lcc}
\hline \multicolumn{1}{c}{ Variable } & Normoglycemia & Hypoglycemia \\
\hline MABP $(\mathrm{mm} \mathrm{Hg})$ & $72 \pm 3$ & $(9)$ \\
Heart rate $(/ \mathrm{min})$ & $222 \pm 7$ & $70 \pm 4$ \\
$\mathrm{PaO}_{2}(\mathrm{~mm} \mathrm{Hg})$ & $106 \pm 6$ & $248 \pm 7$ \\
$\mathrm{PaCO}_{2}(\mathrm{~mm} \mathrm{Hg})$ & $37 \pm 1$ & $95 \pm 6$ \\
$\mathrm{pHa}$ & $7.38 \pm 0.02$ & $7.34 \pm 0.05$ \\
$\mathrm{Blood}$ glucose $(\mathrm{mg} / \mathrm{dl})$ & $122 \pm 6.3$ & $22 \pm 3.2 \dagger$ \\
Blood lactate $(\mathrm{mmol} /$ liter $)$ & $1.1 \pm 0.2$ & $1.2 \pm 0.2$ \\
\hline
\end{tabular}

*Values represent means \pm SEM for the number of animals in parentheses.

$\dagger p<0.001$.

of ${ }^{14} \mathrm{C}$-iodoantipyrine in each brain region. $\mathrm{rCBF}$ was calculated according to the following equation:

$\mathrm{rCBF}(\mathrm{ml} / 100 \mathrm{~g} / \mathrm{min})=$

$$
\frac{(\mathrm{nCi} \text { in brain } / \mathrm{g})}{(2.22 \times 10 \mathrm{dpm} / \mathrm{nCi})(1.57 \mathrm{ml} / \mathrm{min}) \times 100}
$$

Statistical analysis of the data was carried out using the twotailed Student's $t$ test and linear regression analysis.

\section{RESULTS}

Systemic physiologic data on five normoglycemic and nine hypoglycemic newborn dogs at the time of the CBF measurements are shown in Table 1 . The two groups were comparable with regard to $\mathrm{MABP}$, heart rate, $\mathrm{paO}_{2}, \mathrm{paCO}_{2}, \mathrm{pHa}$, and blood lactate. As expected, blood glucose concentrations in the hypoglycemic animals were significantly lower than those of the control animals. Blood glucose concentrations in the former group ranged from 1 to $35 \mathrm{mg} / \mathrm{dl}$.

Blood flow to 20 selected regions of newborn dog brain during normoglycemia and hypoglycemia are shown in Figure 1. Significant increases in blood flow, ranging from 158 to $446 \%$ of control, occurred in 17 of the 20 analyzed structures. In no structure was blood flow decreased. Linear regression analysis of each individual structure failed to reveal a progressive increase in CBF with decreasing blood glucose concentrations of less than $35 \mathrm{mg} / \mathrm{dl}$. Grouping the percent increases in CBF according to major regions of brain ${ }^{1}$ indicated a relative preferential perfusion of the brainstem compared to cerebral cortex, hippocampus, diencephalic gray matter nuclei, cerebellum, and white matter $(p<0.01)$. Visual inspection of the autoradiograms also suggested relatively greater increases in blood flow to brainstem rather than to forebrain or cerebellar structures (Fig. 2).

\section{DISCUSSION}

The present investigation indicates that hypoglycemia is associated with essentially global increases in perinatal CBF as has been shown to occur in mature animals, including man (12, 20, 21). Thus, hypoglycemia joins hypoxia, hypercapnic acidosis, and seizures as the major metabolic stresses known to produce substantial vasodilation of the cerebral circulation (22-24). Indeed, the CBF responses of the newborn dog brain to hypoglycemia appear to be as great as those observed during other insults

\footnotetext{
' Cerebral cortex: frontal cortex, parietal cortex, occipital cortex; hippocampus; diencephalon: caudate nucleus, globus pallidus, thalamus, hypothalamus; brainstem: lateral geniculate body, red nucleus, superior colliculus, inferior colliculus, basis pontis, vestibular nucleus, superior olivary nucleus, medulla; cerebellum: cerebellar hemisphere, cerebellar vermis; white matter: corpus callosum, subcortical white matter.
} 

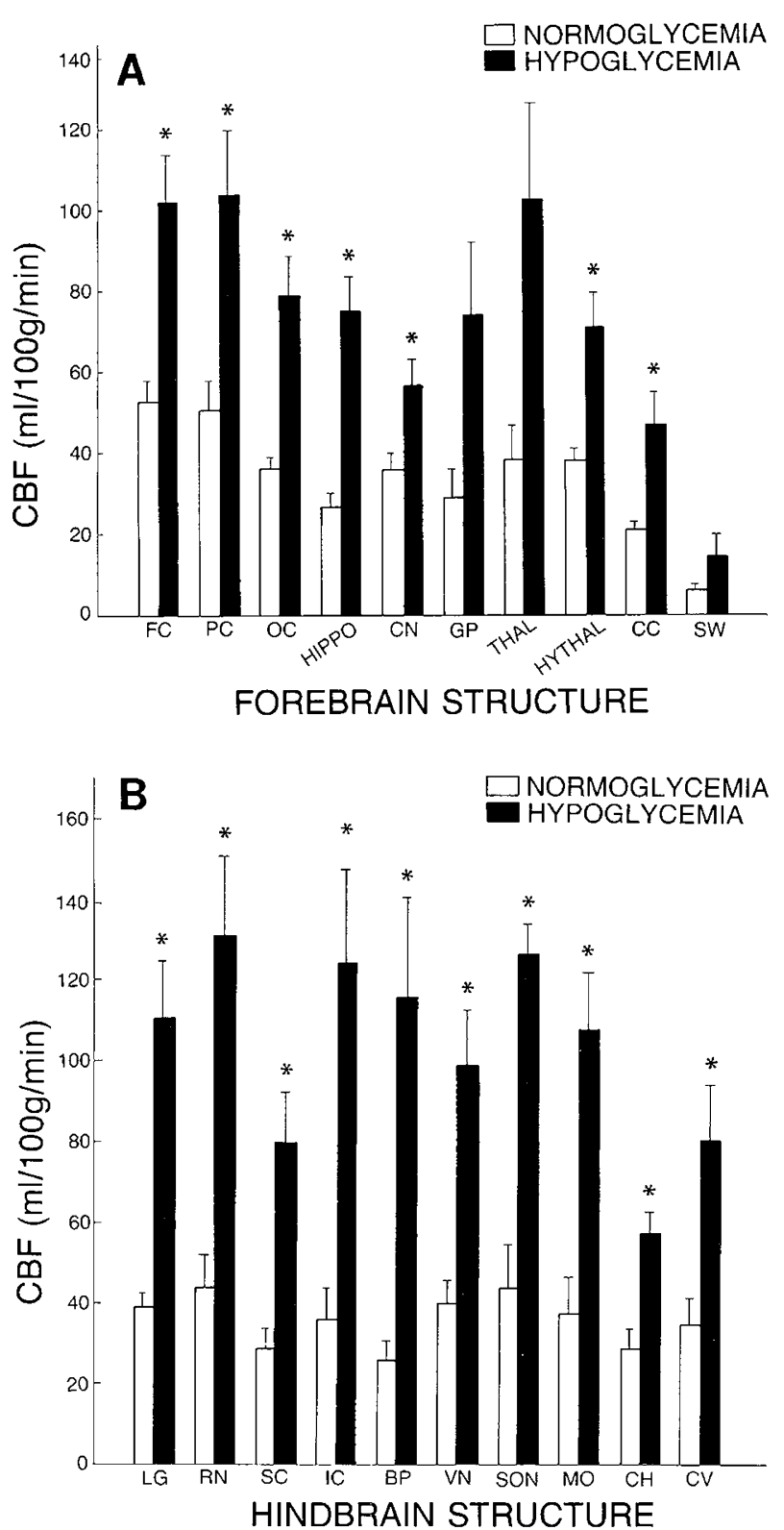

Fig. 1. rCBF in normoglycemic and hypoglycemic newborn dogs. Vertical bars represent means $\pm 1 \mathrm{SE}$ of five normoglycemic and nine hypoglycemic puppies. $* P<0.05$. $F C$, frontal cortex; $P C$, parietal cortex; $O C$, occipital cortex; $H I P P O$, hippocampus; $C N$, caudate nucleus; $G P$, globus pallidus; THAL, thalamus; $H Y T H A L$, hypothalamus; $C C$, corpus callosum; $S W$, subcortical white matter; $L G$, lateral geniculate body; $R N$, red nucleus; $S C$, superior colliculus; $I C$, inferior colliculus; $B P$, basis pontis; $V N$, vestibular nucleus; $S O N$, superior olivary nucleus; $M O$, medulla oblongata; $\mathrm{CH}$, cerebellar hemisphere; $\mathrm{CV}$, cerebellar vermis.

to brain, although regional variations do exist. During normotensive hypoxia $\left(\mathrm{paO}_{2} \simeq 15 \mathrm{~mm} \mathrm{Hg}\right.$ ), 1 - to 2 -fold increases in CBF occur but with a substantial preferential perfusion of the lower brainstem and with a blunted response of white matter structures $(19,25)$. A similar hierarchy of blood flow responses to hypercapnia has been described, with those brain structures possessing the highest basal flows exhibiting the greatest elevations during acidosis $(19,26)$. Convulsive-induced increases in rCBF of newborn dog brain are relatively uniform in nature (27) and, therefore, mimic most closely the present findings of hypoglycemia-induced hyperemia. Indeed, seizures may have contributed to the increases in $\mathrm{CBF}$, although convulsive activity has not been observed in newborn dogs until blood glucose levels fall below $12 \mathrm{mg} / \mathrm{dl}$ (a single animal in our study) (28). Possibly, the underlying pathophysiologic mechanisms producing increased rCBF during hypoglycemia and seizures are similar but differ from that of hypoxia/hypercapnia (see below).

In a previous communication from our laboratory, Hernandez et al. (14) measured CBF in newborn dogs during insulin-induced hypoglycemia. In that study, cerebral cortical blood flow was determined using a modification of the original Kety-Schmidt technique (29), using ${ }^{133}$ Xenon as the diffusible indicator. In that study and unlike the present findings, CBF was unchanged from control in eight hypoglycemic puppies in which blood glucose concentrations averaged $9 \mathrm{mg} / \mathrm{dl}$ (range $4-13 \mathrm{mg} / \mathrm{dl}$ ). An explanation for the discrepant results of the two studies is the fact that in the former investigation all of the hypoglycemic animals exhibited significant lactacidemia and an associated systemic hypotension with MABP ranging from 22 to $50 \mathrm{~mm} \mathrm{Hg}$ (mean $30 \mathrm{~mm} \mathrm{Hg}$ ). In the present study, systemic physiologic homeostasis was more stable with MABP in the hypoglycemic puppies near identical to those of the normoglycemic animals (Table 1). This observation prompted us to correlate the alterations in MABP and in CBF obtained in the two investigations (Fig. 3), inasmuch as lactacidemia per se does not influence rCBF (30). The data show a positive correlation between systemic blood pressure and cerebral cortical blood flow, suggesting that CBF autoregulation is abolished during hypoglycemia (see also Refs. 31 and 32). Thus, as in hypoxia, hypercapnia, and seizures, hypoglycemia appears to render the perinatal brain passive to fluctuations in systemic blood pressure $(22,24)$. If substantiated by further experiments, the finding would have relevance to newborn human infants, in whom systemic hypotension superimposed on hypoglycemia might influence the presence of clinical manifestations as well as ultimate brain damage.

It is reasonable to assume that the elevations in $\mathrm{CCBF}$ during hypoglycemia promote optimal substrate delivery to the perinatal brain during systemic glucose deficiency. Indeed, the enhanced glucose delivery provides adequate glucose equivalents for energy production via oxidation until blood glucose concentrations decline below $10 \mathrm{mg} / \mathrm{dl}$, at which point alternate exogenous and endogenous fuels are required for cerebral metabolism $(14,28)$. In a more recent investigation from our laboratory, Mujsce et al. (33) measured regional cerebral glucose utilization by the 2deoxyglucose technique of Sokoloff et al. (34) in newborn dogs subjected to hypoglycemia with a mean blood glucose concentration of $17 \mathrm{mg} / \mathrm{dl}$. Hypoglycemia was associated with no or relatively minor decreases in glucose consumption in 13 of 16 analyzed structures of brain, indicating that the compensatory increases in blood flow to these regions were sufficient to maintain physiologic glucose metabolism. Brainstem regions exhibited the smallest reductions in glucose utilization, owing to maximal increases in $\mathrm{CBF}$ and glucose delivery, as in our study. In contrast, subcortical white matter showed the poorest blood flow response with resultant greatest decline in glucose utilization. The findings target white matter as that region of brain most vulnerable to the damaging effect of perinatal hypoglycemia.

Richardson et al. (35) have published the only other investigation pertaining to $\mathrm{rCBF}$ responses of the perinatal brain to hypoglycemia. Fetal lambs near term received a constant intravenous infusion of insulin over $4 \mathrm{~h}$, during which blood glucose decreased from a control level of 17 to $12 \mathrm{mg} / \mathrm{dl}(-30 \%)$. Blood flow to five major regions of brain was measured with radioactive microspheres. No major alterations in systemic physiologic or acid-base homeostasis occurred during the infusion $\left(\mathrm{paO}_{2}\right.$ decreased slightly). In contrast to the present findings in newborn dogs, CBF actually declined in cerebral cortex and diencephalon, whereas flows to pons, medulla, and cerebellum were unchanged from control. Thus, blood flows were better preserved in hindbrain than in forebrain structures (see above). The absence of a hyperemic response to insulin infusion may have related to the physiologic low blood glucose levels $(<20 \mathrm{mg} / \mathrm{dl})$ and to the dilated cerebrovascular bed produced by the relatively hypoxic environment both of which characterize the sheep fetus.

The physiochemical mechanisms responsible for the increases 

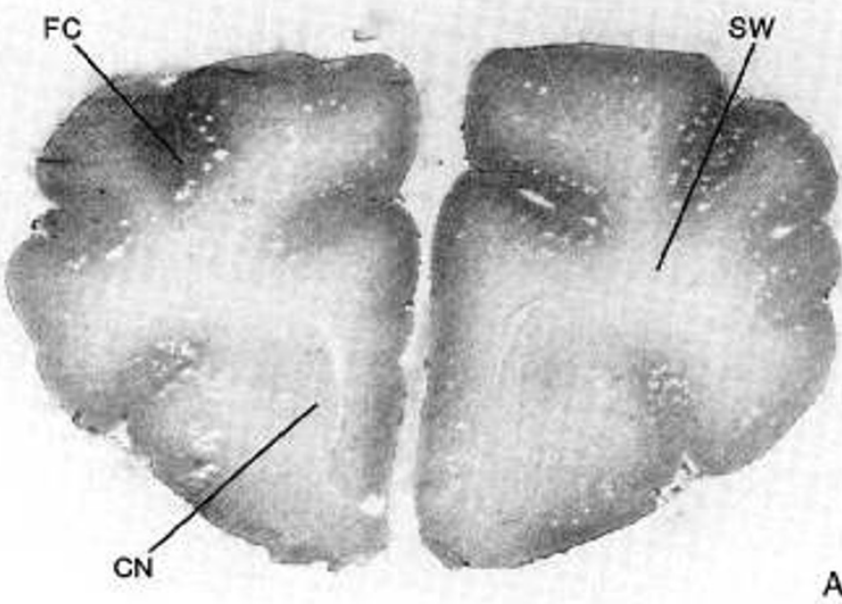

A
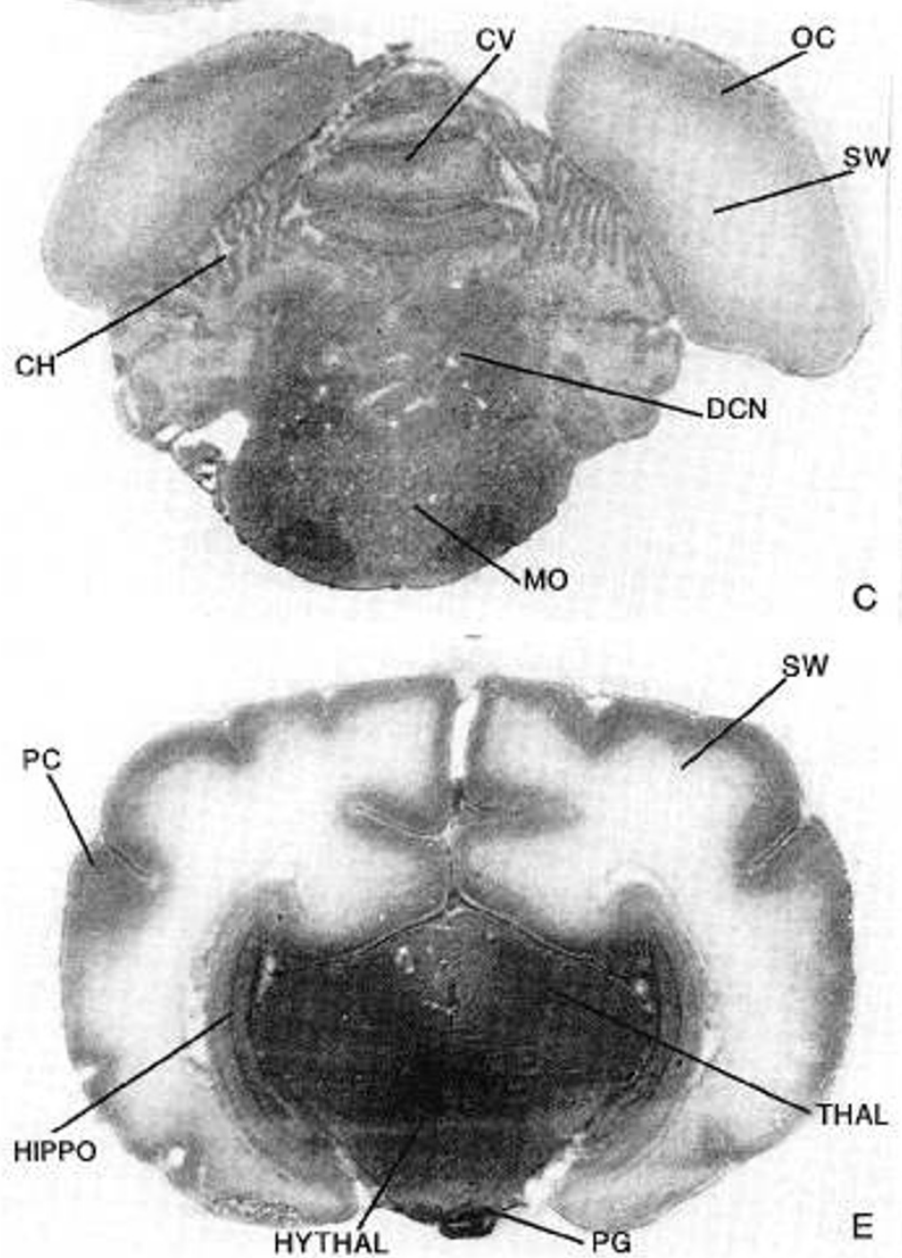

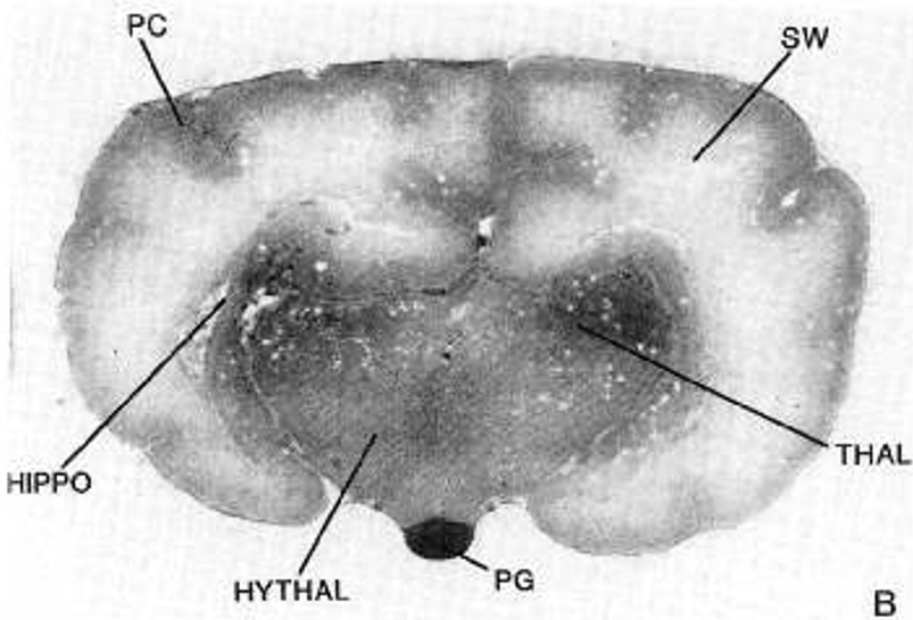

B

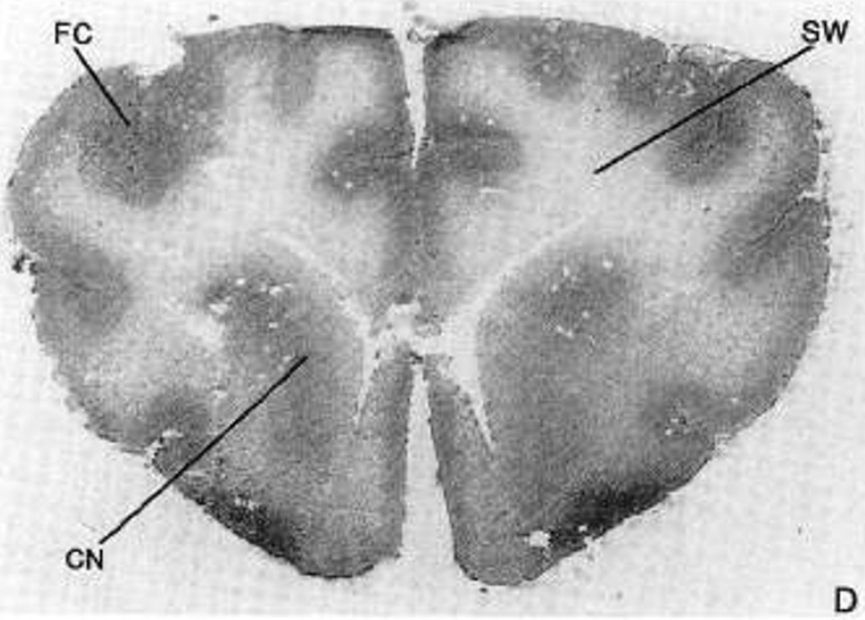

D

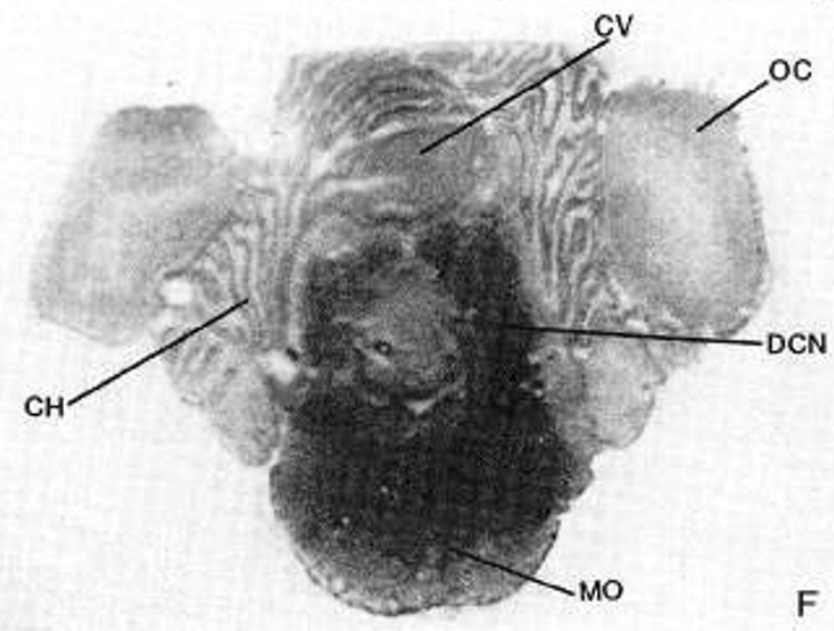

Fig. 2. Representative $\mathrm{CBF}$ autoradiograms during normoglycemia and hypoglycemia. Shown are coronal sections of a brain from a normoglycemic $(A, B, C)$ and a hypoglycemic $(D, E, F)$ newborn dog. Darker areas represent regions of increased $C B F$. $F C$, frontal cortex; $P C$, parietal cortex; $O C$, occipital cortex; HIPPO, hippocampus; THAL, thalamus (pulvinar); HYTHAL, hypothalamus; $C N$, caudate nucleus; $S W$, subcortical white matter; $P G$, pituitary gland; $M O$, medulla oblong ata; $C V$, cerebellar vermis; $C H$, cerebellar hemisphere; $D C N$, deep cerebellar nuclei.

in $\mathrm{rCBF}$ during hypoglycemia presently are not entirely clear. The vasodilatory response of cerebral blood vessels to systemic hypoxia and hypercapnia presumably results from increased $\mathrm{H}^{+}$ ion concentrations in the resistance vessels (arterioles) of the brain $(22,24)$. This mechanism readily explains why those brain regions with the greatest intrinsic metabolic activity (e.g. brainstem) exhibit the greatest increases in blood flow under these conditions. However, during hypoglycemia in adult animals; brain tissue, if anything, is more oxidized than during normoglycemia $(22,36,37)$, and studies in newborn dogs suggest an undisturbed cerebral redox state even at blood glucose concentrations as low as $5 \mathrm{mg} / \mathrm{dl}(28)$. Adenosine accumulation in brain as a cause of cerebral vasodilation $(38,39)$ also cannot explain the hyperemic response to hypoglycemia, inasmuch as the ade- 


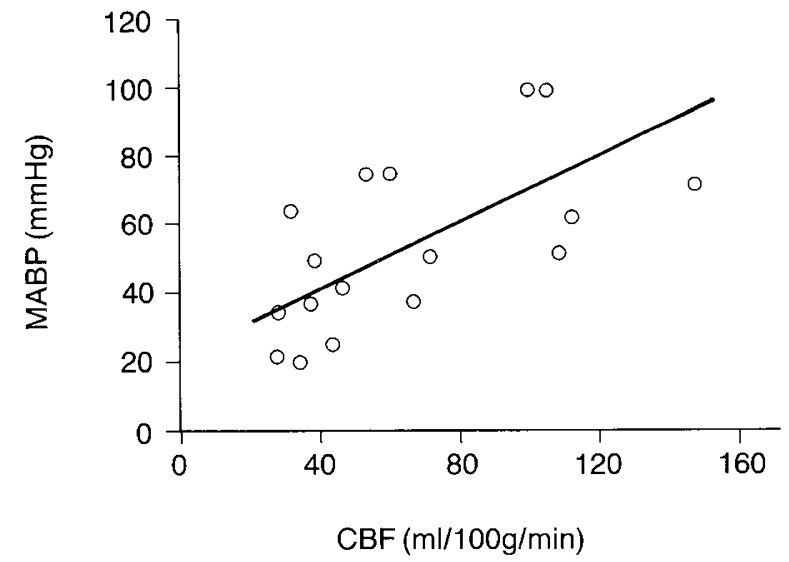

Fig. 3. Relationship between MABP and CBF during hypoglycemia. Values include those of the present study and of normalized values from Hernandez et al. (14). Linear regression analysis: $r=0.71 ; p<0.01$.

nine nucleotides, the major source of adenosine, are well preserved in newborn dog brain even at the extremes of hypoglycemia (28).

Bryan et al. (21) recently demonstrated a close correlation between increases in $\mathrm{rCBF}$ and elevated plasma concentrations of epinephrine and norepinephrine during hypoglycemia in adult rats. The investigators speculated that adrenergic stimulation of $\beta$-receptors in brain might cause or contribute to the global alterations in CBF. Confirmation of their proposal was provided by Hollinger and Bryan (40), who were able to partially or completely abolish the regional hyperemic responses to hypoglycemia by pretreating adult rats with the $\beta$-receptor blocker, propranolol. Presumably, a similar mechanism underlies the cerebrovascular response of newborn dogs to hypoglycemia.

Acknowledgments. The authors thank Francesca Vasta for her expert technical assistance and Thomas Hegyi, I. Mark Hiatt, and Anne Koons for their helpful suggestions and support.

\section{REFERENCES}

1. Pildes R, Forbes AE, O'Connor SM 1967 The incidence of neonatal hypoglycemia. J Pediatr 70:876-884

2. Lubchenco LO, Bard HL 1971 Incidence of hypoglycemia in newborn infants classified by birth weight and gestational age. Pediatrics 47:831-838

3. Neligan GA, Robson E, Watson J 1963 Hypoglycemia in the newborn. Lancet 1:1282-1284

4. Guberlet RL, Cornblath M 1976 Neonatal hypoglycemia revisited 1975. Pediatrics 58:10-17

5. Senior B 1973 Neonatal hypoglycemia. N Engl J Med 289:790-802

6. Hawthorne JC, McRae KN 1965 The neurological and developmental effects of neonatal hypoglycemia: a follow-up of 22 cases. Can Med Assoc J 92:861865

7. Griffiths AD, Bryant GM 1971 Assessment of effects of neonatal hypoglycemia: a study of 41 cases with matched controls. Arch Dis Child 46:819-827

8. Koivisto M, Blanco-Sequeiros M, Krause U 1972 Neonatal symptomatic and asymptomatic hypoglycemia: a follow-up study of 151 children. Dev Med Child Neurol 14:603-614

9. DeLeeuw R, DeVries IJ 1976 Hypoglycemia in small-for-date newborn infants. Pediatrics 58:18-21

10. Shelley HJ, Neligan GA 1966 Neonatal hypoglycemia. Br Med Bull 22:34-39

11. Della Porte P, Maiolo AT, Negri VU, Rosella E 1964 Cerebral blood flow and metabolism in therapeutic insulin coma. Metabolism 13:131-140

12. Norberg K, Siesjö BK 1976 Oxidative metabolism of the cerebral cortex of the rat in severe insulin-induced hypoglycemia. J Neurochem 26:345-352
13. Mann LE, Ducin S, Halverstram J, Mastrantonio J, Weiss R, Schulman J 1973 The effects of hypoglycemia on fetal brain function and metabolism. Am J Obstet Gynecol 117:45-50

14. Hernandez MJ, Vannucci RC, Salcedo A, Brennan RW 1980 Cerebral blood flow and metabolism during hypoglycemia in newborn dogs. $J$ Neurochem 35:622-628

15. Geiger A 1958 Correlation of brain metabolism and function by the use of a brain perfusion method in vitro. Physiol Rev 38:1-20

16. Lowry OH, Passonneau JV 1972 A Flexible System of Enzymatic Analysis. Academic Press, New York

17. Vannucci RC, Duffy TE 1974 Influence of birth on carbohydrate and energy metabolism in rat brain. Am J Physiol 226:933-940

18. Van Uitert RL, Levy DE 1978 Regional brain blood flow in the conscious gerbil. Stroke 9:67-72

19. Cavazzuti M, Duffy TE 1982 Regulation of local cerebral blood flow in normal and hypoxic newborn dogs. Ann Neurol 11:247-257

20. Abul-Rahman A, Agardh CD, Siesjö BK 1980 Local cerebral blood flow in the rat during severe hypoglycemia, and in the recovery period following glucose injection. Acta Physiol Scand 109:307-314

21. Bryan RM, Hollinger BR, Keefer KA, Page BB 1987 Regional cerebral and neural lobe blood flow during insulin-induced hypoglycemia in unanesthetized rats. Cereb Blood Flow Metabol 7:96-102

22. Siesjö BK 1978 Brain Energy Metabolism. Wiley, Chichester, England

23. Vannucci RC 1981 Metabolic and neuropathological consequences of experimental febrile seizures and status epilepticus. In: Nelson KB, Ellenberg JH (eds) Febrile Seizures: Long-Term Management of Children with Fever Associated Seizures. Raven Press, New York, pp 43-57

24. Vannucci RC, Hernandez MJ 1981 Perinatal Cerebral Blood Flow. In Sinclair JC, Warshaw JB, Bloom RS (eds) Perinatal Brain Insult: Mead Johnson Symposium on Perinatal and Developmental Medicine, no. 17. Mead Johnson and Co., Evansville, IN, pp 17-29

25. Ment LR, Stewart WB, Duncan CC, Pitt BR 1986 Beagle puppy model of perinatal cerebral insults: cerebral blood flow changes and intraventricular hemorrhage evoked by hypoxemia. J Neurosurg 65:847-850

26. Shapiro HM, Greenberg JH, Naughton KVH, Reivich 1980 Heterogenecity of local cerebral blood flow- $\mathrm{PaCO}_{2}$ sensitivity in neonatal dogs. J Appl Physiol 49:113-118

27. Young RSK, Osbakken MD, Briggs RW, Yagel SK, Rice DW, Goldberg S $1985{ }^{31} \mathrm{P}$ NMR study of cerebral metabolism during prolonged seizures in the neonatal dog. Ann Neurol 18:14-20

28. Vannucci RC, Nardis EE, Vannucci JS, Campbell PA 1981 Cerebral carbohydrate and energy metabolism during hypoglycemia in newborn dogs. Am J Physiol 9:R192-R199

29. Kety SS, Schmidt CF 1945 The determination of cerebral blood flow in man by the use of nitrous oxide in low concentrations. Am J Physiol 143:53-66

30. Powell CL, Hernandez MJ, Vannucci RC 1985 The effect of lactacidemia on regional cerebral blood flow in the newborn dog. Dev Brain Res 17:314-316

31. Nilsson B, Agardh DC, Ingvar M, Siesjö BK 1981 Cerebrovascular response during and following severe insulin-induced hypoglycemia: $\mathrm{CO}_{2}$ sensitivity, autoregulation, and influence of prostaglandin synthesis inhibition. Acta Physiol Scand 111:455-463

32. Siesjö BK, Ingvar M, Pelligrino D 1983 Regional loss of autoregulation during severe insulin-induced hypoglycemia. J Cereb Blood Flow Metabol 3(suppl 1): S658-S659

33. Mujsce DJ, Boyer MA, Vannucci RC 1987 Regional cerebral blood flow and glucose metabolism during hypoglycemia in newborn dogs. Ann Neurol 22:429(abstr)

34. Sokoloff L, Reivich M, Kennedy C, Des Rosiers MH, Patlak CS, Pettigrew $\mathrm{KD}$, Sakurada O, Shinohara M 1977 The $\left({ }^{14} \mathrm{C}\right)$ deoxyglucose method for the measurement of local cerebral glucose utilization: theory, procedure and normal values in the conscious and anesthetized albino rat. J Neurochem 28:897-916

35. Richardson BS, Hohimer AR, Bissonnette JM, Machida CM 1985 Insulin hypoglycemia, cerebral metabolism and neuronal function in fetal lambs. Am J Physiol 248:R72-R77

36. Bryan RM, Jöbsis FF 1986 Insufficient supply of reducing equivalents to the respiratory chain in cerebral cortex during severe insulin-induced hypoglycemia in cats. J Cereb Blood Flow Metab 6:286-291

37. Pelligrino D, Siesjö BK 1981 Regulation of extra- and intracellular $\mathrm{pH}$ in the brain in severe hypoglycemia. J Cereb Blood Flow Metab 1:85-96

38. Heistad DD, Marcus ML, Gourley JK, Busija DW 1981 Effect of adenosine and dipyridamole on cerebral blood flow. Am J Physiol 240:H775-H780

39. Winn HR, Rubio R, Berne RM 1981 The role of adenosine in the regulation of cerebral blood flow. J Cereb Blood Flow Metabol 1:239-244

40. Hollinger BR, Bryan RM 1987 A beta receptor mediated increase in cerebral blood flow during hypoglycemia. Am J Physiol 253:H949-H955 